\title{
Effectiveness of Irrigation Water Distribution System in Enhancing Rice Cropping Index at Subak Padanggalak, Kedewatan Irrigation Area, Bali
}

\author{
Ratna Komala Dewi, Nyoman Parining, I Wayan Widyantara \\ ${ }^{1}$ Faculty of Agriculture, Udayana University, Bali, Indonesia.
}

Received date: 12 February 2019, Accepted date: 15 May 2019, Online date: 3 June 2019

\author{
Address for Correspondence: \\ Ratna Komala Dewi, Department of Agribisnis Faculty of Agriculture, Udayana University, Bali, Indonesia \\ E-mail:ratnadewi61@ymail.com
}

Copyright (C) 2019 by authors and American-Eurasian Network for Scientific Information.

This work is licensed under the Creative Commons Attribution International License (CC BY).

http://creativecommons.org/licenses/by/4.0/

\section{(C) (i) Open Access}

\begin{abstract}
One way that can be done to increase rice production is the expansion of the harvest area by increasing the rice crop index. Irrigation water supply at certain times is increasingly scarce so that proper management of irrigation water by subak is needed to increase agricultural productivity. Therefore, this study aimed to determine the effectiveness of irrigation water distribution systems in Subak Padanggalak, under the Kedewatan Irrigation Area, Bali. The effectiveness parameter of the water distribution system was specified by using the percentage of area covered from water distribution in Subak Padanggalak throughout the year. The results of the analysis show that the water distribution system is useful as it was able to irrigate the all-area Subak Padanggalak throughout the year adequately. The existing rice cropping index is $250 \%$, and the potential index of food crops is $300 \%$.
\end{abstract}

KEYWORDS

effectiveness, water distribution system, subak, cropping index.

\section{INTRODUCTION}

Rice, as a staple food in Indonesia, including in Bali, is a top priority in increasing food production. The population growth rate and the relatively high level of rice consumption require a continuous increase in rice production. One way to increase food production is to expand the harvest area. On the other hand, the conversion of paddy fields for non-agricultural activities in Bali has decreased by 143.33 ha per year from 2004 to 2013 [1].

The amount of rice that is very high can be fulfilled with various scenarios, among others, by increasing crop intensity or cropping index. The results of the study [2] state that the increase or decrease in the potential for planting depends on the potential for water availability and the extent of the irrigation area. Also, the fallow area can be reduced by selecting the right cropping pattern. The concept of cropping index is also intended to optimize space and time so that the crop index can be maximized. This program can be used as a breakthrough alternative to policy to boost national production. The increase in cropping index in principle is an effort to optimize water and land resources with the right technology.

Management of water resources is needed to intensify farming productivity to preserve food security and increase farmers' income. Water plays an essential role in plant growth. Water serves to ensure the continuity of 
the physiological and biological processes of plants and to maintain soil moisture so that groundwater is in a condition that is easily absorbed important for plants.

Rice is one of the plants that are tolerant of watery or inundated soil conditions. The potential for irrigation water availability is influenced by the availability of water in the area where the amount can be estimated from rainfall. The pattern of availability of irrigation water is very dependent on rainfall patterns and the hydrological order of the rain catchment areas of each reservoir and weir. In agricultural developmen, especially irrigated agriculture, Bali has subak which regulates water supply for plants. This activity is the main function of subak in meeting the water needs of subak members in farming. The subak system is able to anticipate the problem of lack of irrigation water in the dry season, by setting cropping patterns in accordance with the chances of success through irrigation management with the basics of harmony and togetherness [13].

Subak is a socio-religious irrigation and agriculture institution mainly engaged in water management for crop production a year especially rice based on the principle of Tri Hita Karana [11]. THK philosophy implies that human happiness can be achieved if humans are able to maintain harmony between the three elements of THK, namely (1) divine elements (parhyangan), (2) human elements (pawongan), and (3) natural elements (palemahan) $[13 ; 11 ; 8]$. The main function of subak is to allocate irrigation water to produce food.

Subaks in Bali are spread in several irrigation areas. One of the irrigated areas in Bali which has a relatively large area is the Kedewatan Irrigation Area which has a potential area of 2,946.91 ha. The Kedewatan Irrigation Area irrigates 77 subaks from upstream to downstream [7].

Subak Padanggalak is a subak located in the lower reaches of the Kedewatan Irrigation Area and is located in an urban area prone to land conversion. If subak does not play a role in the distribution and borrowing of irrigation water when deficit of irrigation water, the pattern of subak function management is not optimal, this is because not all paddy fields can be cultivated, and irrigation water is a scarce resource [5;4]. If this happens, it tends to decrease the crop index in paddy fields.

\section{OBJECTIVES}

This study aimed to determine the effectiveness of irrigation water distribution system at Subak Padanggalak, under the Kedewatan Irrigation Area, Bali.

\section{Research Area}

\section{MATERIALS AND METHODS}

The research area was in Subak Padanggalak, Kedewatan Irrigation Area, Bali Province which was determined purposively based on several considerations, namely (1) Padanggalak Subak is a subak located in the lower part of the irrigation area and located in an urban area which is prone to land conversion ; (2) Padanggalak Subak has a relatively wide area of 110 ha and has seven unit munduk.

\section{Data collection}

The types of data collected were quantitative and qualitative data. The source of research data collected from primary and secondary data. Primary data, namely data and information sourced from the first party or obtained directly from the informant/respondent with the interview method. Primary data include characteristics of the Research Area.

The research area was in Subak Padanggalak, Kedewatan Irrigation Area, Bali Province which was determined purposively based on several considerations, namely (1) Padanggalak Subak is a subak located in the lower part of the irrigation area and located in an urban area which is prone to land conversion ; (2) Padanggalak Subak has a relatively wide area of 110 ha and has seven munduk (tempek).

\section{Data collection}

The types of data collected were quantitative and qualitative data. The source of research data collected from primary and secondary data. Primary data, namely data and information sourced from the first party or obtained directly from the informant/respondent with the interview method. Primary data include characteristics of farmers, general conditions of Subak Padanggalak, while secondary data, namely data in the form of documents/publications/other reports that support primary data sources. Secondary data is sourced from second parties or government agencies related to research, such as the BPS of the Province of Bali, the Office of Technical Services in the City of Denpasar, and the Province of Bali.

Data collection was done through observation, interviews, and documentation studies. Observations were made on irrigation water distribution activities, while interviews were conducted using a questionnaire to obtain data related to the effectiveness of irrigation water distribution systems in increasing cropping indexes. 
RatnaKomalaDewi et al., 2019. Effectiveness of Irrigation Water Distribution System in Enhancing Rice Cropping Index at SubakPadanggalak, Kedewatan Irrigation Area, Bali /American-Eurasian Journal of Sustainable Agriculture. 13(2): 48-54.DOI: 10.22587/aejsa.2019.13.2.5

Documentation studies are used to complete data from observations and interviews. Subak irrigation water distribution system is a system of allocating, distributing, and lending irrigation water to irrigate paddy fields of subak members.

The population of the study were 299 members of the Padanggalak Subak who were spread over seven units Munduk on Subak Padanggalak consists of 1. Munduk Gendang, 2. Munduk Batuaji, 3. Munduk Pasekan, 4. Munduk Delundung, 5. Munduk Kertasari, 6. Munduk Dauh Biaung, and 7. Munduk Tangtu. 75 people obtained the number of samples based on the Slovin Method with an error tolerance limit of $10 \%$. Sampling was done by random sampling method. To enrich the discussion, data will also be used in-depth interviews (in-depth interviews) with key informants.

\section{Data analysis method}

The data analysis method used was quantitative and qualitative descriptive adapted to the research objectives as follows. The effectiveness parameter of the water distribution system was determined by using the percentage of area covered from the water distribution of Subak Padanggalak throughout the year. In this study, the rice cropping index and the behavior of subak members in facing the availability of irrigation water were also analyzed.

1. To find out the level of effectiveness of the irrigation water distribution system, it is measured by the area index value [9]. The Area Index (AI) formula is:

$$
\mathrm{AI}=\frac{\text { Irrigated Area }}{\text { Area Design }} \times 100 \%
$$

Irrigated area is the area covered by water distribution of Subak Padanggalak throughout the year. Area design is the area that was designed covered by Subak Padanggalak irrigation water throughout the year. The higher AI value is the more effective system of the subak irrigation water distribution.

2. Cropping index $(\mathrm{CI})$ is the ratio between the total planting area and the raw area in a year. To find out the potential cropping index $(\mathrm{CI})$ is calculated by the equation:

$$
\mathrm{CI}=\frac{(\text { PARS }+ \text { PADS1 }+ \text { PADS2) }}{\text { Raw Area }} \times 100 \%
$$

Where: PARS $=$ Planted area for the rainy season

PADS1 $=$ Planted area for dry season 1

PADS2 = Planted area for dry season 2

Raw area $=$ area available for planting

3. To find out the behavior of subak members in facing the availability of irrigation water using a qualitative descriptive method.

\subsection{Characteristics of Respondents}

\section{RESULTS AND DISCUSSION}

The unit of analysis in this study was subak. The characteristics of the respondents in this study focused on age, farming experience, basic livelihood, length of education, arable land area, and farmer's status. The average age of respondents was 60.41 years; average farming experience for 30.33 years; basic livelihood as a farmer as much as $69.33 \%$; length of formal education for 7.71 years; arable land area of 36.79 acres; the status of farmers as cultivators was $35.29 \%$ and the status of farmers as land tenant was $64.71 \%$. This shows that farmers were still in the productive age; relatively long experience in farming; most farmers had basic livelihoods as farmers; however, $64.71 \%$ of farmers were a land tenant. The farmer's education is relatively low, which is equivalent to graduating from elementary school, and the average cultivation area was relatively low, ( $<0.50 \mathrm{ha})$.

\subsection{Description of the Research Area}

Padanggalak Subak is in the area of Kertalangu Village, East Denpasar District, Denpasar City, with boundaries: North is Gatot Subroto Street, East is Menguntur River, South is Ayung River, and West is Ayung 
RatnaKomalaDewi et al., 2019. Effectiveness of Irrigation Water Distribution System in Enhancing Rice Cropping Index at SubakPadanggalak, Kedewatan Irrigation Area, Bali /American-Eurasian Journal of Sustainable Agriculture. 13(2): 48-54.DOI: 10.22587/aejsa.2019.13.2.5

River. For its farming activities, Subak Padanggalak obtained irrigation water from the Yeh Lauh River. Subak Padanggalak has an area of 110 ha. This subak has empelan, Bedugul Temple, and seven munduk (part of subak). Subak Padanggalak obtained irrigation water from the dam in Penatih Village and the upstream subak.

The division of tasks in Subak Padanggalak is as follows.

1. Pekaseh (head of subak). Pekaseh is in charge of leading activities in subak. Pekaseh's tasks are related to five subak functions, namely leading the allocation, distribution and borrowing of irrigation water; lead mutual cooperation in the maintenance of subak facilities, especially irrigation canals, manage the use of subak resources, organize conflict resolution if there are conflicts, convey information from the government to subak members, lead the implementation of ritual activities, coordinate with other institutions. In Subak Padanggalak, the wife of Pekaseh and the wife of the subak member helped prepare the facilities for the ritual activities in Subak.

2. Head of munduk. Head of munduk is in charge of assisting Pekaseh in carrying out internal duties in each subak.

3. Kesinoman. The directions are in each submission, having the task of helping kelian submit the announcement or the results of the subak meeting decision to the subak members in the munduk.

4. Members. All subak members in Subak Padanggalak are active members (karma pengayah). Active members are subak members involved in implementing all subak functions.

\subsection{Pattern of Irrigation Water supply}

The availability of irrigation water in Subak Padanggalak depends on the availability of water in Kedewatan weir and rainfall. Subak Padanggalak obtained a stable distribution of irrigation water, which was 198 1/sec from 2001 to 2016 because the availability of irrigation water in Kedewatan Dam was sufficient. n this study, the efficiency of the availability of irrigation water in tertiary channels was assumed to be $65 \%$ of the discharge provided by the Public Works Service [12]. Rainfall can affect the availability of irrigation water. The average rainfall in the Subak Padanggalak region from 2000 to 2016 fluctuates with an average of $165.82 \mathrm{~mm}$. November to March the average rainfall is relatively high (above average), ranging from $183.56 \mathrm{~mm}$ to 425.07 $\mathrm{mm}$. June to September the average rainfall is relatively low and the lowest in August, which is $12.54 \mathrm{~mm}$ [3]. In general, the pattern of irrigation water supply in Subak Padanggalak is based on water discharge given by the Departement PU and the average rainfall from 2000 to 2016 can be seen in Figure 1.

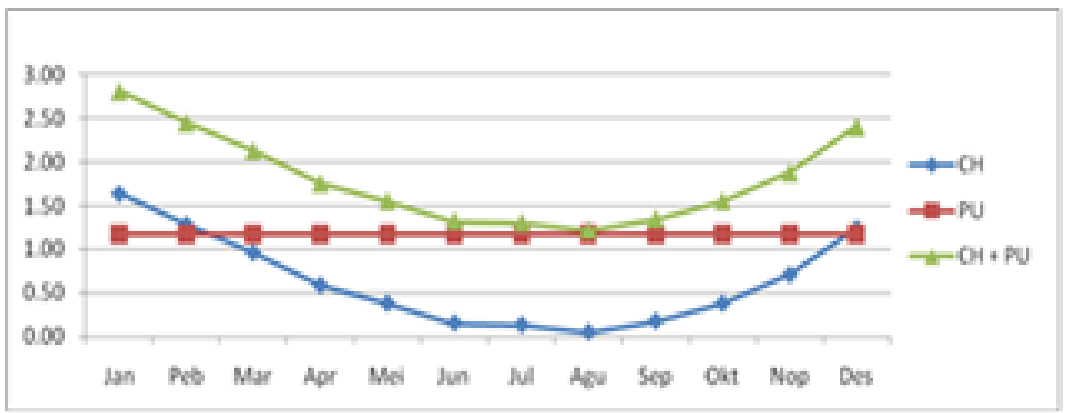

Figure 1. The pattern of Subak Padanggalak Irrigation Water Supply

Information:

$\mathrm{CH}$ : average rainfall

PU: water discharge is given by the Department of Public Works (Departemen Pekerjaan Umum)

In Figure 1 it can be seen that the water availability in Subak Padanggalak is highest in January, which is $2.81 \mathrm{lt} / \mathrm{sec} / \mathrm{ha}$, then starting in February the availability of water decreases and the lowest in August is 1.22 1t/sec/ha. Water availability is increasing again starting in September. Based on interviews with respondents, in Subak Padanggalak irrigation water is always available throughout the year for farming activities.

\subsection{Effectiveness of Irrigation Water Distribution Systems}

The raw area of Padanggalak Subak is 110 ha. This raw area is the area of design or target in the distribution of irrigation water. Under normal circumstances, every planting season for all Subak Padanggalak land is irrigated, so that all land can be cultivated. The purpose of normal conditions is that there is no repair of 
irrigation canals, which causes the closure of irrigation water gates, which results in being unable to do farming. By the concept of the effectiveness of irrigation water distribution systems according to [9], namely the comparison of the irrigated area with area design, the irrigation water distribution system is effective as it was able to fully water the all-area Subak Padanggalak throughout the year. That is, all target paddy fields can be irrigated, so that farming activities can be carried out.

The irrigation water distribution system in Subak Padanggalak can be effectively achieved because between subak, munduk, and among the subak members implement a continuous water distribution system and use the one channel inlet and outlet method. Subak, munduk, and subak members receive irrigation water according to their rights, then use water according to their needs and excess irrigation water is channeled to the drainage channel.

In rice farming, soil processing activities require the most water. To meet water requirements when processing land, subak regulates alternating water distribution by borrowing irrigation water. Water borrowing is also carried out among farmers if they experience a lack of water so that all farmers can grow rice in each growing season. This indicates that subak can distribute irrigation water evenly.

\subsection{Cropping Index}

Padanggalak Subak has two soil textures, namely clay and sandy clay. The clay texture is located on the north side of Ida Bagus Mantra Street with pH 6.0 and sandy clay on the south side of Ida Bagus Mantra Street with pH 7.0 [6]. Soil texture can provide clues about the types of plants suitable to be planted on the land. The main crops cultivated in Subak Padanggalak in 2016 are food crops, especially rice. In the awig-a wig it was agreed that $10 \%$ of paddy fields could be planted with crops other than rice. Farmers in Subak Padanggalak apply rice-rice cropping patterns. In the subak meeting, a schedule for processing land and planting schedules were established.

Determination of planting schedules has been agreed upon at the subak meeting. Most farmers do not carry out planting outside the agreed schedule, with reasons, among others, to avoid pest attacks and have no trouble finding penebas at harvest. Schedule of rice farming activities in Subak Padanggalak for the two 2016 planting seasons for rice-rice cropping patterns can be seen in Figure 2.

\begin{tabular}{|c|c|c|c|c|c|c|c|c|c|c|c|c|}
\hline $\begin{array}{c}\text { Planting } \\
\text { season }\end{array}$ & & & & I & & & & & & & & \\
\hline \multirow{2}{*}{ Month } & $\mathrm{Jan}$ & Peb. & Mar & Apr & Mei & Jun & Jul & Aug & Sep & Oct & Nop & Des \\
\hline & '16 & "16 & "16 & "16 & $" 16$ & "16 & '16 & 16 & $=16$ & "16 & " 16 & ${ }^{\prime} 16$ \\
\hline Activities & & & & & & & & & & & & \\
\hline
\end{tabular}

Figure 2. Schedule of Rice Farming Activities in Subak Padanggalak in 2016

Information:

processing land for approximately 20 days,

planting - harvesting approximately 115 days

In Figure 2, it can be observed that the tillage period in Padanggalak Subak is quite long, which is around 20 days per planting season. At the time of processing the land, the farmers do seed nurseries for about 15 days. Aside from being caused by water supply for tillage, the length of land processing is also caused by the limited number of tractor operators.

Farmers carry out the planting pattern continuously. The age of rice in Subak Padanggalak is around 115 days. Varieties that are often used by Padanggalak Subak farmers are Ciherang and IR 64. If in one rice planting season it takes around 135 days or 270 days (nine months) for two rice planting seasons, meaning that in two years it can carry out rice farming five times. That is, if the farmer follows the cropping pattern set at the subak meeting, the rice cropping index in Padanggalak Subak is $250 \%$. If the remaining three months in each year are used to grow palawija, which is relatively short, for about three months, the crop index can be increased to $300 \%$. Palawija farming can be cultivated during the dry season.

Besides palawija farming, it can increase the crop index; it can also break the cycle of rice pest disease. Another thing that needs to be considered if farmers will plant palawija is the availability of labor for harvesting and marketing the results. In this case, the need for subak empowerment in helping the marketing of the products of its members. Based on these considerations, Subak Padanggalak has the opportunity to increase 
RatnaKomalaDewi et al., 2019. Effectiveness of Irrigation Water Distribution System in Enhancing Rice Cropping Index at SubakPadanggalak, Kedewatan Irrigation Area, Bali /American-Eurasian Journal of Sustainable Agriculture. 13(2): 48-54.DOI: 10.22587/aejsa.2019.13.2.5

cropping indexes and reduce the risk of pest and disease attacks, if (a) tractor operators are available in the appropriate amount; (b) there are clear labor and markets available for secondary crops

\subsection{The behavior of Subak Members in Facing Irrigation Water Supply Patterns}

In Subak Padanggalak irrigation water is available throughout the year. The behavior carried out by subak members in facing the pattern of water supply is

1. Subak members apply five times to plant rice in two years. Growing rice continuously causes problems, namely pest and plant diseases. Therefore, it needs to be interspersed with secondary crops to break the cycle of plant pests and diseases.

2. Subak members who get the turn of land cultivation, they are prioritized using irrigation water. If the water needed is not enough, then borrowing is done. This is usually done during tillage and flooding during planting in the dry season. This strategy is carried out by all subak members.

3. A small proportion of farmers $(5.09 \%)$ have diversified rice with secondary crops, such as sweet corn, flowers, and Ipomoea reptana. Diversification is generally carried out by perceptive farmers who have enough family workers for farming activities. Also, these farmers are generally located in the most downstream region of Subak Padanggalak, where the water debit is relatively low.

\section{CONCLUSIONS}

Irrigation water distribution system is effective as it was able to fully water the all-area Subak Padanggalak throughout the year. The existing rice cropping index in Padanggalak Subak is $250 \%$ and the potential index of food crops is $300 \%$. The behavior of subak members in dealing with patterns of availability of irrigation water in Subak Padanggalak, is (a) apply five times to plant rice in two years; (b) members who have the turn to process land are prioritized using irrigation water (borrowing irrigation water); (c) diversifying rice with secondary crops for subak members who obtain relatively small water debit.

The suggestion in this study is that farmers need to diversify rice with secondary crops so they can break the pest cycle and can increase the crop index.

\section{ACKNOWLEDGMENTS}

The researcher would like to thank all those who helped in this research. On this occasion, the researcher expressed their gratitude to the Institute for Research and Community Service of Udayana University, Faculty of Agriculture, Pekaseh Subak Padanggalak, Observers of the Kedewatan Irrigation Area, and students who helped collect data in the field.

\section{AUTHORS' CONTRIBUTION}

Ratna Komala Dewi and Nyoman Parenting developed the idea and had an essential role in the result, material section, and the abstract submission. I Wayan Widyantara performed the statistical analysis and the discussion.

\section{Funding/Support}

\section{FINANCIAL DISCLOSURE}

The project was funded by the Institute for Research and Community Service of Udayana University, Faculty of Agriculture.

\section{REFERENCES}

[1] Badan Pusat Statistik (BPS) Provinsi Bali. 2014. Bali Dalam Angka 2014.http://bali.bps.go.id/ flipbook/Bali\%20Dalam\%20Angka\%202014.

[2] Barus, H. 2001. Potensi Peningkatan Indeks Pertanaman Berdasarkan Pola Ketersediaan Air Irigasi di Sumatera Bagian Utara (Skripsi). Bogor: Institut Pertanian Bogor.

[3] BBMKG Wilayah III Denpasar. 2017. Data Unsur Iklim Bulanan.

[4] Dewi, K.D., W. Windia, D.P. Darmawan, I W. Budiasa. 2014. Simulation Subak Management Function Optimally in Subak Lodtunduh, Bali, Indonesia. Journal of Economics and Sustainable Development. ISSN: 2222-1700. Vol.5, No. 28, pp 111-118.

[5] Dewi, K.D. 2015. Optimalisasi Pengelolaan Fungsi Sistem Subak di Daerah Irigasi Kedewatan, Provinsi Bali (Disertasi). Denpasar: Universitas Udayana. Laboratorium Ilmu Tanah Universitas Udayana. 2013. Hasil Analisis Tanah. Fakultas Pertanian Universitas Udayana. Denpasar.

[6] Laboratorium Ilmu Tanah Universitas Udayana. 2013. Hasil Analisis Tanah. Fakultas Pertanian Universitas Udayana. Denpasar. 
RatnaKomalaDewi et al., 2019. Effectiveness of Irrigation Water Distribution System in Enhancing Rice Cropping Index at SubakPadanggalak, Kedewatan Irrigation Area, Bali /American-Eurasian Journal of Sustainable Agriculture. 13(2): 48-54.DOI: 10.22587/aejsa.2019.13.2.5

[7] Pengamat Daerah Irigasi Kedewatan. 2017. Data Subak Daerah Irigasi Kedewatan. Kedewatan, Gianyar.

[8] Peraturan Daerah Provinsi Bali No. 9 Tahun 2012 tentang Subak. Denpasar.

[9] Ramadhan, F. dan A.P.M.Tarigan. 2013. Evaluasi Kinerja Jaringan Irigasi Jeuram Kabupaten Nagan Raya, Departemen Teknik Sipil Universitas Sumatera Utara

[10] Sutawan, N. 2005. Subak Menghadapi Tantangan Globalisasi. Dalam: Pitana, I G. dan I G.A.P. Setiawan, editor. Revitalisasi Subak dalam Memasuki Era Globalisasi. Yogyakarta: Penerbit Andi.

[11] Sutawan, N. 2008. Organisasi dan Manajemen Subak di Bali. Denpasar: Pustaka Bali Post.

[12] Wigati, S. dan Zahab, R. 2010. Analisis Hubungan Debit dan Kehilangan Air Pada Saluran Irigasi Tersier di Daerah Irigasi Pungkur Utara Ranting Dinas Pengairan Pungkur Lampung Tengah. Lampung: Jurusan Teknik Pertanian Fakultas Pertanian, Universitas Lampung.

[13] Windia, W., S. Pusposutardjo, N. Sutawan. 2005. Transformasi Sistem Irigasi Subak Yang Berlandaskan Konsep Tri Hita Karana. Jurnal Sosial-Ekonomi Pertanian dan Agribisnis (SOCA) Vol. 5 No. 2 Juli 2005, Program Studi Agribisnis, Fakultas Pertanian Universitas Udayana. Denpasar. pp. 229-235. 